\title{
THE INFLUENCE OF LIQUID SMOKE ON THE CHEMICAL CHARACTERISTICS OF SALTED EGG
}

\author{
Diterima 28 Agustus 2017; diterima pasca revisi 6 Oktober 2017 \\ Layak diterbitkan 31 Oktober 2017 \\ Jeki Mediantari Wahyu Wibawanti ${ }^{1)^{*}}$, Ma Meihu ${ }^{2)}$, Qiu Ning $^{2)}$, HintonoO ${ }^{3,}$ and Y. B. Pramono ${ }^{3)}$ \\ ${ }^{1}$ Department of Animal Science, University of Muhammadiyah Purworejo, Purworejo 54111, Indonesia. \\ ${ }^{2}$ National $R \&$ D Center for Egg Processing, Collage of Food Science and Technology, Huazhong Agricultural University, \\ Hubei-China. \\ ${ }^{3}$ Department of Animal Science, Diponegoro University, Indonesia.
}

\begin{abstract}
Salted egg is easily preserved of egg products. The making process was added liquid smoke. Therefore, the objective was to determine chemical characteristics (yolk index, oil exudation and salt content) of duck egg salted. Completely Randomized Design (CRD) was used throughout the research. They were run triplicate with differences concentration of liquid smoke (control, 1\%, and 1.25\%). They were differences salting time process $(0,1,2,3$, and 4 weeks). Yolk index of control sample were no different statically compared to that of salted egg with liquid smoke treatment $(p>0.05)$. Significant different of yolk index ( $p<0.05)$ increased along with increase of salting time (4 weeks). Significant differences $(p<0.05)$ were found on oil exudation of control sample compared to that salted egg with presence of liquid smoke. Oil exudation of salted egg yolk increased with increasing salting time ( $p<$ $0.05)$ up to 4 weeks. Significant differences $(p<0.05)$ were obtained on the salt content of control compared to that salted egg white treatment of liquid smoke. Salt content white increased along with the increase of salting time $(p<0.05)$.
\end{abstract}

Key words: salted egg, liquid smoke, yolk index, oil exudation, salt content

\begin{abstract}
ABSTRAK
Telur asin adalah salah satu produk pengawetan telur yang sangat populer dan mudah untuk dilakukan. Tujuan dari penelitian ini adalah untuk mengetahui karakteristik kimia (indeks kuning telur, eksudasi minyak, dan kadar garam telur asin itik). Metode yang digunakan adalah percobaan dengan Rancangan Acak Lengkap (RAL). Perlakuan terdiri dari konsentrasi penggunaan (kontrol, $1 \%$ dan $1.25 \%)$ dan perbedaan lama pengasinan (1,2,3 dan 4 minggu). Indeks kuning telur kontrol tidak berbeda nyata $(p>0,05)$ di antara perlakuan, tetapi berbeda nyata $(p<0.05)$ pada peningkatan lama pengasinan. Pada eksudasi minyak berbeda nyata diantara perlakuan. Eksudasi minyak meningkat dengan peningkatan lama perendaman. Kadar garam berbeda nyata $(p<0,05)$ diantara perlakuan.
\end{abstract}

Key words : Telur asin, Asap cair, Indeks kuning telur, Eksudasi kadar garam 


\section{INTRODUCTION}

Egg has a high quality protein. It is also contains various vitamin and minerals. However, the eggs were damaged easily because of many factors as microbiological, physical and chemical. Salted egg is one of the most traditional preserved egg products. Salted egg process is coating the egg with soil paste mixed with salt for about 15-30 days (Chi and Tseng, 1998).Usually, salted eggs made duck eggs. The characteristics of product are better than chicken eggs ( $\mathrm{Li}$ and $\mathrm{Hsieh}, 2004)$.

The desirable of salted egg include orange color, oil exudation, and gritty texture ( $\mathrm{Li}$ and Hsieh, 2004; Kaewmanee et al., 2009 ${ }^{b}$ ). Salt can be used as food additive, not only mainly for preserving, but also for improving the taste of the product (Fuentes et al., 2010).

Nowadays, process making salted egg has been diverse into smoked-salted egg. The other food preservation method is traditional smoking. The traditional way of smoking was substituted by Liquid smoke (LS) (Wibawanti et al., 2014). LS are being used as antimicrobial agents, antioxidant potential and sensory properties (Paul et al., 2005). Smoked-salted egg with LS treatment may have impact on the antibacterial properties, antioxidant activity, and product acceptability. Therefore, the objectives of this study were to investigate the changes on the chemical characteristics of duck egg salted by LS at different times such as yolk index, oil exudation, and salt content.

*Corresponding author:

Jeki Mediantari Wahyu Wibawanti

Email :jekiwibawanti@gmail.com

Department of Animal Science, University of

Muhammadiyah Purworejo, Purworejo 54111, Indonesia

\section{MATERIALS AND METHODS}

The research has been done at the Laboratory of National Research and Development Center for Egg Processing, Food Science and Technology Collage, Huazhong Agricultural University, Wuhan, Hubei Province, China. The materials were prepared in making salted egg were: fresh duck eggs (Anas platyrhynchos), liquid smoke of coconut shell, salt, and some of chemicals.

\section{Salted Egg Process}

Salted egg process was determined according to the method Wibawanti et al., (2014). Collected of duck eggs (Anas platyrhynchos) were obtained with a weight range $65-75 \mathrm{~g}$, less than 3 days after laying. Split Plot in time with a basic design Completely Randomized Design (CRD) was used throughout the research. They were run triplicate. The main plot treatments were supplementation of LS with differences concentration (control, 1\% LS, and $1.25 \% \mathrm{LS})$. The sub plot treatments were salting time process $(0,1,2,3$, and 4 weeks). Statistical analysis was done by the statistical program the SAS 9.13 system for windows. Data was presented as mean value with standard deviations where the confidence level at $p<0.05$. One-way analysis of variance (ANOVA) was carried out and means comparisons were done using Duncan's multiple range tests.

How to cite:

Wibawanti, J.M.W., Ma, M., Qiu, N., Hintono, \& Pramono, Y.B. (2017). The Influence of Liquid Smoke on The Chemical Characteristics of Salted Egg. Jurnal Ilmu dan Teknologi Hasil Ternak, 12 (2), 76-82. 


\section{Determination of Yolk Index}

Yolk index was measured to know yolk quality. Salted egg yolk measurements were performed using calipers. Yolk index was performed according method by Bhale et al., (2003) The salted yolk index was calculated as proportion yolk height to yolk width.

\section{Determination of Salt Contents}

Salted egg white was separated from egg yolk. Samples $( \pm 2 \mathrm{~g})$ were selected and added hot water $50 \mathrm{ml}$. The solution transferred quantitatively into a $250 \mathrm{ml}$ volumetric flask of this homogenized sample. Solution was taken and added with $25 \mathrm{ml}$ into $250 \mathrm{ml}$ Erlenmeyer flash and added $25 \mathrm{ml}$ water. Solution was added with $1 \mathrm{ml} \mathrm{K}_{2} \mathrm{CRO}_{4}(1 \%)$ as indicator. The mixture was titrated with $\mathrm{AgNO}_{3} 0.1$ mol until the solution became permanently light brown. The percentage of salt calculated as follows based on Can (2011).

\section{Determination of Oil Exudation of Salted Egg Yolk}

Oil exudation was determined according to the method of Lai et al. $(1997 ; 1999 ; 2010)$ with slight modification. Oil exudation was defined as the proportion of free to total lipid content. Total lipid content was done by methods as follow: Yolk egg measured approximately $3 \mathrm{~g}$. The 35 $\mathrm{ml}$ n-hexane and 2-propanol were prepared with ratio 3:2 (v/v). They were mixed using homogenizer at $5000 \mathrm{rpm}$ for 10 minute. The filtrate obtained by Whatman No. 1 filter paper. They were evaporated in a temperaturecontrolled water bath at $55{ }^{0} \mathrm{C}$. Then they were dried at temperature $105^{\circ} \mathrm{C}$ in an oven until constant weight.

The free lipid content was done by method as follow: yolk (5 g) was mixed with $25 \mathrm{ml}$ distilled water and homogenized at $5000 \mathrm{rpm}$ for 30 second. The homogenate was centrifuged at
$9500 \times g$ for $30 \mathrm{~min}$ at temperature $25^{\circ} \mathrm{C} . \mathrm{N}$ hexane and iso propanol $(25 \mathrm{ml})$ was added to the supernatant to dissolve the float. They mixed with ratio 3:2 (v/v). The solvent-lipid layer obtained was separated using a separating funnel. The solvent in the solvent-lipid layer was evaporated in a water bath at temperature $55{ }^{\circ} \mathrm{C}$. The residue was heated at $105{ }^{0} \mathrm{C}$ until constant weight was obtained as free lipid.

\section{RESULTS AND DISCUSSION}

\section{Yolk Index of Salted Egg}

Yolk index was defined proportion of yolk eight to yolk width (Bhale et al., 2003; Samli et $a l ., 2005)$. Yolk index obtained from differences concentration of liquid smoke during salting time up to 4 weeks. Yolk index of control sample were no different statistically compared to that of salted egg with liquid smoke treatment $(\mathrm{p}>$ 0.05). Significant different of yolk index ( $\mathrm{p}<$ $0.05)$ increased along with increase of salting time (4 weeks). The yolk index of control, $1 \%$, and $1.25 \%$ liquid smoke increased along with increase salting process. They are show in the Fig. 1. The yolk index of control sample and salted egg with presence of liquid smoke $1 \%$, and $1.25 \%$ were found similarly value of $0.87,0.89$, and 0.92 , respectively.

The yolk index of control increased lower than salted egg with treatment of liquid smoke. The differences yolk index in this study may be due to some factors such as liquid smoke, salt, initial egg quality, egg grade, egg size, time storage, and temperature. Liquid smoke have found component such as phenol, guaicol, syringol, carbonyl, and acid derivatives. Salted egg was added with liquid smoke during salting process, it may be used preserve the yolk quality. Yolk quality of salted eggs has been influence of preference consumers. 


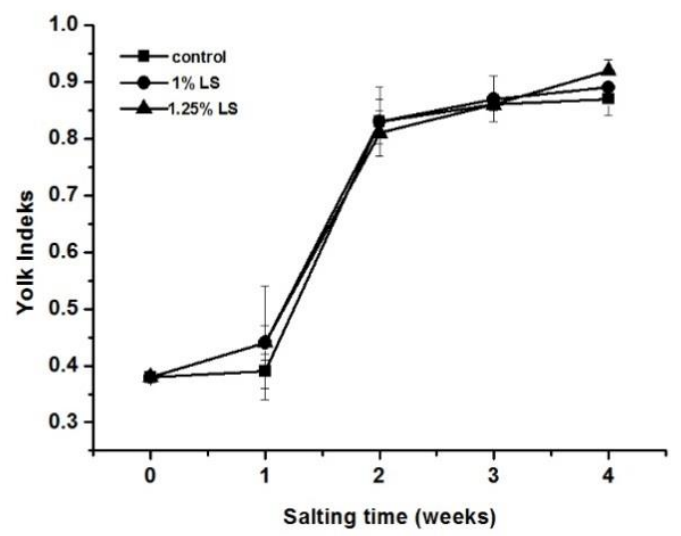

Figure 1. Yolk Index of Salted Egg

The spherical natural of egg yolk can be expressed as yolk index by measuring the yolk height and width. Yolk index was used an indication of freshness. It is indicates a progressive weakening of the vitelline membranes and liquefaction of the yolk caused mainly by diffusion of water from the albumen (Bhale et al., 2003; No et al., 2005; Stadelman, 1995).

\subsection{Oil Exudation of Salted Egg Yolk}

Generally, oil exudation is one of desirable characteristic salted egg (Kaewmanee et al., $\left.2009^{a}, 2011\right)$. Significant differences $(p<0.05)$ were found on oil exudation of control sample compared to that salted egg with presence of liquid smoke. Oil exudation value of all samples was obtained slightly different. The result of oil exudation value was showed in Table 1. Oil exudation of salted egg yolk increased with increasing salting time $(\mathrm{p}<0.05)$ up to 4 weeks.

Table 1. Oil Exudation of Salted Egg Yolk

\begin{tabular}{|c|c|c|c|c|c|}
\hline \multicolumn{6}{|c|}{ Oil Exudation } \\
\hline Treatment & Fresh Egg & 1 Weeks & 2 Weeks & 3 Weeks & 4 Weeks \\
\hline \multicolumn{6}{|c|}{ 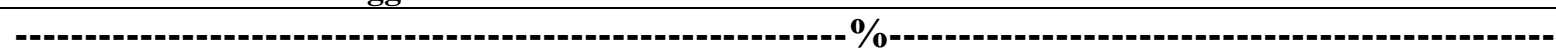 } \\
\hline Control & $2.57 \pm 0.24$ & $9.42^{\mathrm{b}} \pm 0.16$ & $15.21^{\mathrm{c}} \pm 0.28$ & $36.97^{\mathrm{d}} \pm 0.61$ & $52.39^{\mathrm{e}} \pm 0.65$ \\
\hline $1 \% \mathrm{LS}$ & $2.61 \pm 0.18$ & $9.90^{\mathrm{b}} \pm 0.60$ & $16.28^{c} \pm 0.4$ & $37.34^{\mathrm{d}} \pm 0.52$ & $52.67^{e} \pm 1.21$ \\
\hline $1.25 \% \mathrm{LS}$ & $2.70 \pm 0.17$ & $10.95^{\mathrm{c}} \pm 0.49$ & $16.48^{\mathrm{d}} \pm 0.34$ & $37.54^{\mathrm{e}} \pm 0.70$ & $53.03^{\mathrm{f}} \pm 0.86$ \\
\hline
\end{tabular}

Mean \pm SD $(n=3)$, subscript indicates significant differences $(\mathrm{p}<0.05)$

After salting process up to 4 weeks, the oil exudation of egg yolk sample control was increased value from 2.57 to $52.39 \%$. Salted eggs of liquid smoke $1 \%$ were increased value from 2.61 to $52.67 \%$. Oil exudation for salted eggs of liquid smoke $1.25 \%$ was increased value from 2.70 to $53.03 \%$. At the last week of salting, the highest oil exudation of egg yolk was obtained on the product with presence of liquid smoke $1.25 \%$, which it compared with other samples.
Salted egg with presence of liquid smoke was found the thinner egg shell with increased porosity and weaker membrane. It might support the penetration of salt, which was associated with oil exudation and moisture content.

Probably, the presence of salt in yolk and dehydration during salting were enhanced oil exudation. The removal of water from egg yolk was increased the extract lipid. Free lipid might be released from low-density lipoprotein 
micelles. It may due to the structural changes of low-density lipoprotein. In this case induced by dehydration and increased salt content. A lower rate of salting might induce oil exudation more effectively. The denaturation process of yolk proteins as affected by salt might result in a greater loss in their emulsifying properties during salting time. As a consequence, a higher amount of free fat was released (Schultz et al., 1968 in Kaewmanee et al., 2009ª).

\section{Salt Content of Salted Egg}

Salt can be used as food additive, not only mainly for preserving, but also for improving the taste of the product (Fuentes et al., 2010). Salt content of salted egg was presented with different concentration of liquid smoke during salting process up to 4 weeks. Significant differences $(p<0.05)$ were obtained on the salt contents of control sample white compared to that salted egg with treatment of liquid smoke. Salt content values of all samples were slightly different. Salt content of duck egg white increased along with the increase of salting time $(p<0.05)$. Salt contents of salted egg white were depicted in Fig. 2.

The control values of salt content were increased value from initial 0.57 to $5.25 \%$. The salted egg with $1 \%$ liquid smoke was increased value from initial 0.56 to $5.30 \%$. The salted egg with $1.25 \%$ liquid smoke was increased value from initial 0.56 to $5.51 \%$. Salt content of product was obtained the most values with treatment of liquid smoke $1.25 \%$.

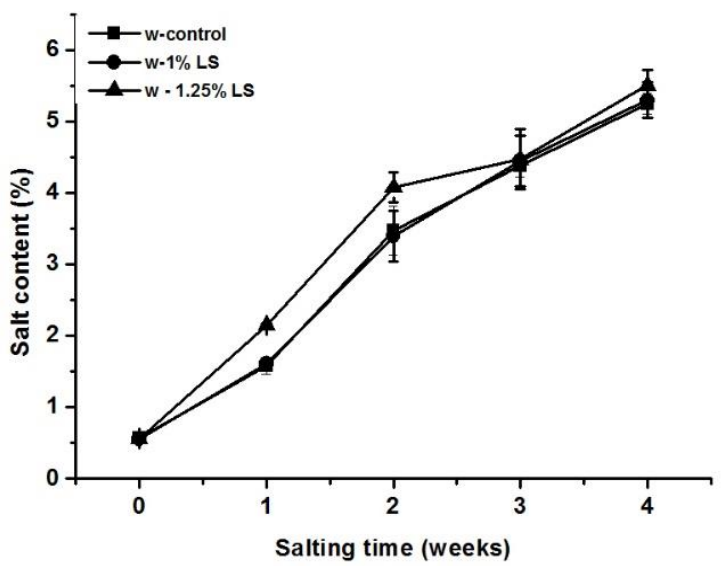

Figure 2. Salt Content of Salted Egg White

Liquid smoke treatments were increased value in the penetration of $\mathrm{NaCl}$ rate both of the albumen and yolk. Salt content in egg white was increased more rapid and higher that found in egg yolk. The result was indicated that penetration salt and liquid smoke trough egg shell, which it mediated by the osmotic process. It was accompanied by an increase in salt content in egg white. The high value of salt content was obtained by great osmotic pressure with different concentration of salt and liquid smoke. The result was occurred a greater migration of salt into the egg shell.

Kaewmanee et al., (2009a $\left.; 2009^{\mathrm{b}}\right)$ found that the increased salt content of egg white was associated with the dehydration of egg yolk mediated by osmotic process. Kaewmanee et al., (2011) reported that no differences in salt content of egg white were pretreated with proteases. Gradually, $\mathrm{NaCl}$ was diffused into the albumen and yolk through the pores, and membrane of the shell during brining in saturated saline Lai et al., (1997). 


\section{CONCLUSIONS}

The results of salted egg product with liquid smoke treatment with differences salting time have influence on the chemical characteristics of salted egg products. The yolk index, oil exudation and salt contents were increase during salting time.

\section{ACKNOWLEDGMENT}

The work was supported by the National R\&D Center for Egg Processing, Collage Food Science and Technology, Huazhong Agricultural University, Ministry of Education Republic of Indonesia and University of Muhammadiyah Purworejo, Indonesia.

\section{REFERENCES}

Bhale, S., No, H. K., Prinyawiwatkul, W., Farr, A. J., Nadarajah, K \& Meyers, S.P. (2003). Chitosan coating improves shelf life of egg. J. Food Sci. 68: 2378-2383. DOI: 10.1111/j.1365-2621.2003.tb05776.x

Can, O. P. (2011). Combine effect of potassium sorbate and dry salting on the shelf life sardine (Sardina pilcardus). Journal of Food Technology. 9 (1). 43-49.

Chi, S. P., \& Tseng, K. H. (1998). Physicochemical properties of salted pickled yolk from duck and chicken eggs. Journal of Food Science, 33: 507-513. DOI: 10.1111/j.1365-2621.1998.tb15668.x

Fuentes, A., Segovia, I.F., Serra, J.A., \& Barat, J.M. (2010). Development of a smoked sea bass product with partial sodium replacement. Journal of Food Science and Technology, 43: 1426-1433. DOI: 10.1016/j.lwt.2010.04.013
Kaewmanee, T., Benjakul, S., \& Visessanguan, W. 2009 ${ }^{\text {a }}$ Changes in Chemical Composition, Physical properties and microstructure of duck as influence by salting. Food Chemistry, 112, 560-569. DOI: 10.1016/j.foodchem.2008.06.011

Kaewmanee, T., Benjakul, S., \& Visessanguan, W. $2009^{\mathrm{b}}$. Effect of salting process on the chemical composition, texture properties and microstructure of duck egg. Journal of the Science of Food and Agriculture. 89, 625-633. DOI: 10.1002/jsfa.3492

Kaewmanee, T., Benjakul, S., \& Visessanguan, W. 2011. Effect on $\mathrm{NaCl}$ on thermal of aggregation of egg white proteins from duck egg. Food Chemistry, 125, 706-712. DOI: $\quad$ 10.1016/j.foodchem.2010.09.072

Kaewmanee, T., Benjakul, S., Visessanguan, W., \& Gamonpilas, C. 2011. Effect of sodium chloride and osmotic dehydration on viscoelastic properties and thermal-induced transitions of duck egg yolk. Food Bioprocess Technology, 6 (2), DOI: 10.1007/s11947-011-0667-7

Lai, K. M., Chung, W.H., \& Han, T. (1997). J.Food Sci Technol. Int. Tokyo. 3 (3): 269273.

Lai, K. M., Chi, S.P., \& Ko, W.C. (1999). Changes in yolk states of duck egg during long-term brining. Journal of Agricultural and Food Chemistry, 47, 733-736. DOI: 10.1021/jf980486r

Lai, K. M., Chung, W.H., Jao, J.L., \& Hsu, K.C. (2010). Oil exudation and effect salted of $\mathrm{NaCl}$ penetration rate on the duck egg granulation and oil off the yolk of salted duck egg histological structures of duck egg yolks during brining. The Journal of Poultry Science 89, 738-744. 
Li, J. \& Hsieh, Y, P. (2004). Traditional Chinese food technology and cuisine. Asia Pasific Journal of Clinical Nutrition, 13, 147-155.

No, H. K., Prinyawiwatkul, W., \& Meyers, S.P. (2005). Comparison of shelf life of egg coated with chitosans prepared under various deproteinization and demineralization times. Journal of Food Science, $\quad 70, \quad 377-382$. DOI: 10.1111/j.1365-2621.2005.tb11459.x

Paul, J. M., Toledo, R. T., \& Ramakrishnan, S. (2005). Determination of minimum inhibitory concentrations of liquid smoke fractions. Journal of Food Science. 70 (1), M12-M17. DOI: 10.1111/j.13652621.2005.tb09040.x

Samli, H. E., Agma, A., and Senkoylu, N. (2005). Effects of storage on egg quality and temperature on egg quality in old laying hen. The Journal of Applied Poultry Research, 14, 548-553.

Stadelman, W.J. (1995). Quality identification shell egg. In Egg Scince and Technologi. Stadelman, W.J and Cotterill, O. J. Food Product Press. An Imprint of the Haworth Press, Inc. New York, London.

Wibawanti, J.M.W., Meihu, M., Qiu, N., Hintono, A., \& Pramono, Y.B. (2014). The Characteristics of salted egg in the presence of liquid smoke.J. Food Applied Food Technol. 1 (1), 1-3. DOI: http://dx.doi.org/10.17728/jatp.v2i2.112 